\title{
Piotr MAŁYSZKO
}

Uniwersytet im. Adama Mickiewicza, Poznań

\section{„Prawda Wileńska”}

W

okresie PRL-u uwaga badaczy zajmujących się historią prasy lat 1939-1945 skupiona była na obszarze Generalnego Gubernatorstwa. Po roku 1989 zwiększyło się zainteresowanie tą częścią II Rzeczypospolitej, która we wrześniu 1939 r. została anektowana przez ZSRR. Losy Wilna w czasie II wojny światowej są o tyle szczególne, że kilkakrotnie zmieniały się w nim władze. Miasto znajdowało się kolejno w rękach sowieckich, litewskich, znowu sowieckich, następnie niemieckich i ponownie sowieckich. $Z$ tego powodu ciekawe są także dzieje prasy wileńskiej w latach 1939-1944. W tej pracy, przedstawiona została historia codziennej prasy polskojęzycznej w Wilnie, wydawanej w latach 1940-1941, a więc w czasie okupacji sowieckiej, ze szczególnym uwzględnieniem najważniejszego dziennika - „Prawdy Wileńskiej”. Podstawowym materiałem źródłowym pracy są gazety wychodzące w omawianym czasie w Wilnie. Tylko znikomy procent ogólnej liczby wydanych numerów uległ zniszczeniu i jest niedostępny. Jako źródła pomocnicze wykorzystane zostały wybrane pamiętniki i wspomnienia wilnian. Wszystkie publikacje poruszające zagadnienie prasy polskiej w Wilnie w latach 1939-1944, obejmują zazwyczaj tylko jedną z trzech części, na jakie dzieli się ten okres, a więc okres litewski, okupację sowiecką i niemiecką. Najobszerniej o polskich gazetach w pierwszym okresie napisał Piotr Łossowski w jednym z rozdziałów książki „Stosunki polsko-litewskie 1939-1940” i Stanisława Lewandowska w „Losy Wilnian. Zapis rzeczywistości okupacyjnej. Ludzie, fakty, wydarzenia 1939-1945”. Jerzego Maśliński w artykule „Prasa w języku polskim na Litwie Radzieckiej” podał jedynie informacje podstawowe, sygnalizując zaledwie istnienie tematu. W tle innych zagadnień pojawia się prasa wileńska w książce Longina Tomaszewskiego „Kronika wileńska 1939-1941” i „Kronika wileńska 1941-1945”.

Międzywojenne dzieje Wilna zakończyły się 18 września 1939 roku. Po raz ostatni ukazały się w tym dniu gazety codzienne. W nocy z 18 na 19 września miasto zajęły oddziały Armii Czerwonej. 28 września Ribbentrop i Mołotow skorygowali plany podziału Polski i rozgraniczenia 
stref wpływów w Europie Wschodniej z dnia 23 sierpnia 1939 r. Trzy państwa nadbałtyckie znalazły się w sferze wpływów Moskwy. Ale Stalin nie od razu dokonał ich inkorporacji, mając na uwadze opinię światową, czekał na lepszy moment. Wobec Litwy wykazał nawet wspaniałomyślność i na mocy porozumienia podpisanego 10 października 1939 r., przekazał jej Wileńszczyznę, w zamian za zgodę na utworzenie na terytorium kraju baz wojskowych. Tydzień później oddziały Armii Czerwonej opuściły miasto, 28 października wkroczyły do niego wojska litewskie.

Władze litewskie początkowo nie wyraziły zgody na wydawanie polskich gazet. Sądziły, że w „odzyskanej” stolicy państwa powinna ukazywać się przede wszystkim prasa litewska. Powoli docierała do nich świadomość, że niewielu ludzi skłonnych byłoby po nią sięgnąć. Według badań statystycznych z 1938 roku $^{1}$, wśród ok. 208 tys. mieszkańców miasta, Polaków było 137200 (66\%), Żydów 58800 (28,3\%), Rosjan 7800 (3,8\%), Białorusinów 1600 (0,5\%), Litwinów 1100 (0,5\%), innych narodowości 1300 (0,5\%). We wrześniu 1939 r., w Wilnie znalazła schronienie spora grupa uchodźców, w większości Polaków i Żydów. Do 2 grudnia 1939 r. zarejestrowało się ich 18 311, do 25 lutego ok. 36 000. Władze litewskie znalazły się w obcym otoczeniu. Musiały jednak w końcu pogodzić się z rzeczywistością, szukać sposobów przemówienia do społeczeństwa polskiego, do tego niezbędna wydawała się gazeta. Wybrano najprostsze rozwiązanie - umożliwiono kierownictwu przedwojennego „Kuriera Wileńskiego” wznowienie działalności. Zezwolenie na wydawanie tego dziennika uzyskał profesor Witold Staniewicz. „Kurier Wileński”, który ukazał się 2 listopada 1939 roku miał numer 259, był jedynym dziennikiem kontynuującym działalność po klęsce wrześniowej. Wilno zaś stało się jedynym miastem II Rzeczypospolitej, w której ukazywała się w tym czasie polska prasa. Profesor Staniewicz jako wydawca krótko cieszył się monopolem. 25 listopada 1939 roku pojawiła się bowiem „Gazeta Codzienna”, wydawana i redagowana przez Józefa Mackiewicza. Władzom litewskim z pewnością nie zależało na stworzeniu polskiemu czytelnikowi komfortu wybierania między tytułami. Nowy dziennik miał być bardziej prolitewski, liczono także na zneutralizowanie wpływów „Kuriera” i zantagonizowanie polskiego społeczeństwa. „Gazeta Codzienna” nie spełniła widocznie pokładanych nadziei, skoro postanowiono wydać kolejny dziennik polskojęzyczny - „Nowe Słowo”. Jego pierwszy numer ujrzał światło dzien-

1 Dane podajęza: P. Łossowski, Litwa a sprawa polska, Warszawa 1979, s. 57. 
ne 14 stycznia 1940 roku. „Nowe Słowo” chociaż polskie z języka, z ducha całkowicie było litewskie. Władze litewskie poprzez szereg niepopularnych decyzji źle zapisały się w pamięci ówczesnych mieszkańców Wilna. Nie mogli oni wybaczyć m.in. zdelegalizowania polskich organizacji społecznych, kulturalnych i zawodowych, zacierania zewnętrznych oznak polskości miasta, zmuszanie ludności do nauki języka litewskiego, zlikwidowanie Uniwersytetu Stefana Batorego, wprowadzenia ustawy o obywatelstwie, która dokonała segregacji ludności na „obywateli”, „cudzoziemców” i „obcokrajowców”. Spośród ok. 200000 Wilnian obywatelstwo przyznano niespełna 40 000. Resztę zaliczono do pozostałych kategorii, odmawiano im prawa do pracy, a nawet przejazdów pociagami. Chociaż rządy litewskie nie trwały długo, wystarczyło czasu, aby wytworzyło się wśród ludności polskiej poczucie doznanej, głębokiej krzywdy.

„Gdy uwaga świata zwrócona była na wydarzenia we Francji, ZSRR przystapił do egzekwowania swych «praw» do państw bałtyckich, które zgodnie z układem «o granicy i przyjaźni» z 28 września 1939 roku znalazły się w sowieckiej strefie interesów"2. 15 czerwca 300000 żołnierzy Armii Czerwonej dokonało inwazji na Litwę. Armia litewska nie stawiała oporu. 17 czerwca sformowano nowy, komunistyczny rząd, na którego czele stanął Justas Paleckis. „Polskie społeczeństwo Wilna z ogromnym zaniepokojeniem i obawą przyjęło ponowne przyjście bolszewików. Zdawało sobie dobrze sprawę, że skończył się okres «ulgowy», w którym Wilno było jedynym miejscem w podzielonej między okupantów Polsce, gdzie życie toczyło się w stosunkowo normalnych warunkach"”. Ludność polska w Wilnie miała wiekowe tradycje obrony tożsamości narodowej, dlatego polityka litwinizacji prowadzona przez rząd w Kownie miała niewielkie szanse powodzenia. Władza sowiecka okazała się nieporównywalnie cięższym doświadczeniem. Bronisław Krzyżanowski napisał w pamiętniku „Okupacja sowiecka zmieniła nas w bezkształtną, plastyczną masę, dającą się ugniatać" ". Decydujące były oczywiście siła Armii Czerwonej i terror NKWD, ale nie można nie doceniać roli prasy $\mathrm{w}$ tym smutnym procesie.

Władze sowieckie szybko zlikwidowały niewielką, ale jednak istniejącą niezależność polskich wydawnictw na Litwie i zmieniły je

2 L. Tomaszewski, Kronika Wileńska 1939-41, Warszawa 1988, s. 56.

3 Ibidem, s. 57.

4 B. Krzyżanowski, Matecznik wileński 1939-1944, Paryż 1974, s. 34. 
w posłuszny instrument propagandy. Ostatni numer „Kuriera Wileńskiego" ukazał się 28 czerwca 1940 roku. Po zmianach personalnych redakcja zaczęła wydawać „Gazetę Ludową”, która wychodziła od 29 czerwca do 20 sierpnia. Redaktorem naczelnym był Paweł Bujnicki. „Gazeta Codzienna" ukazywała się pod niezmienionym tytułem. Zmienił się tylko naczelny, dotychczasowego zastapił komisarz Michał Marcińczyk. Po przejęciu władzy na Litwie przez komunistów „Nowe Słowo” nie było już nikomu potrzebne i przestało się ukazywać. „Gazeta Codzienna” i „Gazeta Ludowa" pod zarządem sowieckim były do siebie podobne pod względem prezentowanych wiadomości i opinii. Wiadomości polityczno-wojenne ze świata stopniowo rugowano z pierwszych stron, redukując także ich objętość. Dominujące stały sprawy społeczne i gospodarcze ZSRR. Na wszelkie sposoby wychwalano system państwa. Pierwszą wielką kampanią były,,wybory”, które odbyły się w dniach 14 i 15 lipca. Utworzony po nich Sejm Ludowy 21 lipca ogłosił Litwę Socjalistyczną Republiką Sowiecką, zwracając się równocześnie do Rady Najwyższej o zgodę na przyłączenie tego państwa do ZSRR. 3 sierpnia Rada Najwyższa pozytywnie rozpatrzyła tę prośbę. Wilno stało się stolicą nowej republiki sowieckiej. Wybory z 14 i 15 lipca zostały sfałszowane. Mimo sterroryzowania ludności w Wilnie według ZWZ frekwencja wynosiła około 50\%. Oficjalny komunikat władz ogłoszony w „Gazecie Ludowej” i „Gazecie Codziennej” mówił o 98\%. W styczniu odbyły się kolejne „wybory”, tym razem ludność została zmuszona do „wyboru” towarzysza Iwana Pozdniakowa do Rady Najwyższej ZSRR. Kandydat był wcześniej ambasadorem sowieckim w Kownie, tylko w ten sposób był z Litwą związany. Konkurentów nie miał. Tym razem władze były sprawniejsze, nawet w opinii ZWZ frekwencja wyniosła ponad 90\%, oficjalnie mówiono o 99,8\%. Zastraszanie społeczeństwa przebiegło w szybkim tempie. Obywatele litewscy i „obcokrajowcy” zostali mianowani obywatelami ZSRR dekretem, bez pytania o zgodę, natomiast uchodźcy wojenni mieli możliwość otrzymania obywatelstwa na podstawie próśb przedstawionych władzom. Około 50\% uchodźców obawiając się wysiedlenia przyjęło obywatelstwo sowieckie, co było równoznaczne ze zrzeczeniem się obywatelstwa polskiego.

21 lipca, w pierwszym dniu istnienia Litewskiej Socjalistycznej Republiki Sowieckiej ukazała się polska wersja „Prawdy Komsomolskiej. Organu Wileńskiego Komitetu Miejskiego i Powiatowego LKZM Litwy”. Gazeta od tygodnia wydawana była już w wersji litewskiej. Nakład wynosił 5000 egzemplarzy, redaktorem naczelnym był Algirdas Prokopavičius. 
Pismo liczyło 4 strony, format 54 x $38 \mathrm{~cm}$ i kosztowało 10 kopiejek w 1940 roku, w 1941 podrożało o 5 kopiejek, ostatni numer ukazał się 3 czerwca tego roku. Ta sama redakcja wydawała także polskojęzyczną „Prawdę Pionierską. Organ Wileńskiego Komitetu Miejskiego i Powiatowego LKZM Litwy". Pionierzy i inni zainteresowani mogli ją czytać dwa lub cztery razy w miesiącu, od września 1940 do czerwca 1941 roku.

Pod koniec sierpnia 1940 roku połączono redakcje „Gazety Ludowej” i „Gazety Codziennej”. Po stosownych czystkach powstał zespół redagujący „Prawdę Wileńską”, która ukazywała się do wybuchu wojny sowiecko-niemieckiej. To był najważniejszy dziennik wydawany dla społeczności polskiej w Wilnie i na Wileńszczyźnie w okresie okupacji sowieckiej. W podtytule wpisano: „Organ Wileńskiego Miejskiego i Powiatowego Komitetu Komunistycznej Partii (bolszewików) Litwy oraz Wileńskiego i Powiatowego Komitetów Wykonawczych". Jej pierwszy numer ukazał się 21 sierpnia 1940 roku w nakładzie na początku 10 tysięcy egzemplarzy, ostatni 22 czerwca 1941 r.. W sumie ukazało się 262 numerów. Gazeta miała format 50 x $36 \mathrm{~cm}$, od 4 do 12 stron, kosztowała 15 kopiejek. Funkcje redaktora naczelnego początkowo pełniło kolegium redakcyjne w składzie: Stefan Jędrychowski, Andrzej Nowicki, Jonas Korosas, a później samodzielnie Władysław Sokołowski, jego następcą został Andrzej Nowicki. W redakcji znalazły się następujące osoby: Stefan Jędrychowski, Stefan Świerzawski, Teodor Bujnicki, Mieczysław Krzepkowski, Alfred Łęski, Kazimierz Rubinstein, Jakub Kowalski, Maria Żeromska-Namysłowska, Alina Rebece, Aleksander Minkowski, Antoni Olcha, współpracowali zaś m.in. Henryk Liński, Konstany Szychowski, Józef Maśliński, Anatol Mikułko. Kierownikiem redakcji był Chmielewski. Informacje ze świata i obszaru Związku Sowieckiego dostarczała agencja TASS, z terenu Litwy kowieńska Elta. Sprawozdania z różnego rodzaju zjazdów, sesji, posiedzeń, narad, spotkań władz partyjnych i państwowych, przemówienia towarzyszy, dostarczane były do redakcji z komitetów, których „Prawda Wileńska" była organem. Wiadomości z terenu Wilna i okolic zbierali redaktorzy oraz tzw. ,aktyw autorów i korespondentów”.

Pierwsza strona „Prawdy Wileńskiej” poświęcona była doniesieniom o działalności władz najwyższych ZSRS i LSRS. Mowy ważniejszych dostojników drukowano w całości. Następne dwie poświęcone były sprawom partyjnym, społecznym i gospodarczym kraju. Na pozostałych pisano o sprawach regionalnych i kulturalnych. Na przedostatniej stronie znaleźć można było informacje ze świata, w tym informacje o sytuacji wojennej na zachodzie. Na ostatniej reklamy i ogłoszenia drobne. Nie 
sposób ustalić liczby czytelników „Prawdy Wileńskiej”. Nakład pisma według danych redakcji wzrastał z początkowych 10 tys. do 27 tysięcy. Ilość czytelników na pewno nie wzrosła w takiej proporcji. W porównaniu np. z „Gońcem Codziennym” wychodzącym w czasie okupacji niemieckiej ilość drobnych ogłoszeń była dużo mniejsza. Wskazywać to może na mniejszą poczytność. Redakcja także skarżyła się na zbyt małą ilość odbiorców, tłumacząc niski poziom czytelnictwa spadkiem po czasach „burżuazyjnych”. Wydaje się, że brutalna kłamliwa propaganda bijąca ze stron pisma oraz brak informacji o sprawach naprawdę interesujących Polaków najbardziej odstręczały od sięgnięcia po „Prawdę”. Brak wiarygodności był dla większości czytelników „Prawdy Wileńskiej” oczywisty. „Pięknym słowom o dobrobycie w Związku Sowieckim przeczyła codzienna rzeczywistość" ${ }^{5}$. Ci, którzy kupowali gazety powodowani byli głodem informacji, przyzwyczajeniem, ale też np. chęcią poznania repertuaru kin i teatrów.

Redaktor naczelny, Władysław Sokołowski, członek WKP(b) chociaż podawał się za potomka Tadeusza Kościuszki, z polskością niewiele miał wspólnego, nie mówił nawet po polsku. Każde wydanie gazety musiało być tłumaczone przez dyżurnego dziennikarza na rosyjski. W redakcji codziennie organizowano tzw. „lietuczki”, kilkugodzinne zebrania, na których dziennikarze krytykowali siebie i kolegów, oceniali ostatni numer pisma, planowali następny. Poza zebraniami i pracą w redakcji dziennikarze zmuszeni byli wykonywać prace społeczne i polityczne. W okresie wyborów do Rady Najwyższej ZSRR występowali jako agitatorzy lub mężowie zaufania. Wszyscy musieli należeć także do związków zawodowych, oraz różnych komitetów np. ubezpieczeń społecznych, spraw kulturalnych, płac i produkcji. Delegat komitetu ubezpieczeń musiał na przykład odwiedzać chorych w domu, w szpitalu, troszczyć się o leki i właściwe odżywianie, kontrolować szpitale i polikliniki, sprawdzając czy ich dyrektorzy dobrze dbają o pacjentów.

Propaganda w systemach totalitarnych zawsze odgrywała wielką rolę, w omawianym czasie gazety były jej podstawowymi środkami. „Prawda Wileńska” tak jak cała sowiecka prasa miała wychowywać „,masy w duchu komunistycznym”. W jednym z artykułów pisano: „Prasa radziecka [...] podaje do wiadomości osiagnnięcia Litwy i całego Związku Radzieckiego, biczuje uchylających się od pracy, demaskuje wrogów ludu. Prasa

5 S. Wirski, Polityka ZSRR wobec ziem polskich 1939-1941, Warszawa 1988, s. 28. 
dopomaga do należytego zrozumienia i urzeczywistnienia zarządzeń Partii i Rządu. [...] Przy pomocy prasy radzieckiej, śledzimy wszechstronny rozkwit naszego związku Radzieckiego, z drugiej strony coraz większe ubóstwo ludu pracującego w krajach kapitalistycznych oraz okrucieństwo wojny imperialistycznej”, . O rzetelnym informowaniu czytelników, oddzielania opinii redakcji od faktów nie mogło być mowy. Prasa służyła także komunikacji władzy z ludem. Dzięki niej „Stalin i Partia porozumiewają się z milionami robotników, z niej także można się dowiedzieć, czego Partia i Rząd od was żądają, jakie wydają rozporządzenia, jakich pragną udzielić wam wskazówek, pomóc wam w urządzeniu waszego życia"7. Ta komunikacja nie była jednostronna. Liczne artykuły, reportaże listy do redakcji miały odzwierciedlać ,głos ludu”, który był zadowolony, kochał Stalina i władzę sowiecką i był wdzięczny za potrzebne, a nawet niezbędne rady, rozporządzenia i wskazówki. Zapewniali o swej lojalności przedstawiciele wszystkich grup zawodowych, naukowcy, artyści, robotnicy, chłopi. Nie brakowało znanych w Wilnie nazwisk, odnosiło się wrażenie, że wszyscy poddali się reżimowi. Powstawał obraz społeczeństwa zniewolonego, w którym nie ma miejsca na bunt, czy nawet pojedynczy sprzeciw.

Głównym zadaniem „Prawdy Wileńskiej” było lansowanie tezy, że ZSRR jest najlepszym państwem na kuli ziemskiej. Kraj ten cieszył się olśniewającym powodzeniem dzięki ustrojowi komunistycznemu, którego główne filary to: Stalin, konstytucja, partia komunistyczna i Armia Czerwona. Dzięki nim Związek Sowiecki osiaggnął potęgę gospodarczą, polityczną, militarną i kulturalną. Stalin był obiektem bezustannego kultu, wspominano go niemal w każdym numerze na pierwszej stronie. Surowy przydomek okraszano wymyślnymi epitetami, które przydawać mu miały wielkości, mądrości, geniuszu. Wszystkie jego przemówienia drukowano i określano jako epokowe. Pod nimi notowano zachwyty bliskich współpracowników wodza, a także wypowiedzi robotników i chłopów. Podkreślali oni pozytywny wpływ Stalina na swą pracę i życie. Jego rady wskazówki pomagały rządzącym w planowaniu i podejmowaniu właściwych decyzji, rolnikom w orce, zasiewie i żniwach, pisarzom w nadawaniu głębi pisanym utworom, młodym w odnalezieniu sensu życia, starym w uzyskaniu spokoju. Wszelkie przejawy działalności ludzkiej na obsza-

6 „Prawda Wileńska”, R. 2, nr 145.

7 „Prawda Wileńska”, R. 1, nr 57. 
rze ZSRR, tak fizyczne jak i umysłowe, były według „Prawdy Wileńskiej” przesiąknięte bezpośrednim wpływem myśli Stalina. Jemu przypisywano autorstwo konstytucji Związku Sowieckiego. Uznano ją za dzieło wielkie, przełomowe w dziejach, decydujące o szczęściu narodów, które znalazły się na obszarze jej obowiązywania. „Dla robotników i włościan Litwy rok 1940 znamienny był przez to, że spełniły się tego roku ich wielkie pragnienia. Nad Litwą zaświeciło słońce stalinowskiej konstytucji”» ${ }^{\text {. Po }}$ Stalinie i konstytucji przedmiotem największej adoracji były Wszechzwiązkowa Komunistyczna Partia (bolszewików) [WKP(b)] i Litewska Komunistyczna Partia (bolszewików) [LKP(b)]. Partię utożsamiano z państwem, jej przypisywano wszystkie osiagnnięcia. Ludzie tworzyli „masy” i służyli partii w osiągnięciu celów. Partia była siłą motoryczną postępu, burząc stary porządek i tworząc nowy. Zmiany wymagały nieustającej walki. Komuniści walczyli o: szczęście, socjalizm, komunizm, wzrost produkcji, lepszą wydajność pracy oraz z: analfabetyzmem, szkodnictwem, bezrobociem, kapitalizmem, wstecznictwem etc. Odnosili w tej walce zwycięstwa duże, bardzo duże, decydujące i ostateczne. Kolejny filar państwa, Armię Czerwoną, przedstawiano jako najpotężniejszą siłę militarną świata, czuwającą nieustannie, gotową odeprzeć każdy atak. Rok 1940 przyniósł Związkowi Sowieckiemu nabytki terytorialne: Litwę, Łotwę i Estonię, Besarabię i część Bukowiny. Siły zbrojne komunistycznego państwa w relacjach „Prawdy Wileńskiej” wszędzie witane były z radością. Często po słowach Armia Czerwona następował okolicznik „wyzwolicielka”. Służba w niej miała być największym zaszczytem i honorem, choć przyznawano, że jest ciężka. Chwalono się wielką liczebnością armii, dobrym wyszkoleniem, wyposażeniem w nowoczesny sprzęt techniczny. Dzięki wymienionym czynnikom Związek Radziecki miał wspaniale funkcjonować. Podsumowując rok 1940 napisano w artykule wstępnym: „W krainie socjalizmu na przestrzeni 365 dni wrzała twórcza praca, praca milionów. Wznoszono gmach, który nazwano komunizmem. Rośli ludzie, powstawały nowe talenty. Budowano fabryki. Rozpalano nowe huty. Stawały do szeregu nowe elektrownie. W fabrykach i kołchozach umacniała się dyscyplina pracy, podnosiła się też wydajność. Przeprowadzając konsekwentną politykę pokoju i neutralności, korzystając z wszelkich dobrodziejstw tego pokoju, Związek Radziecki planowo owocnie realizował $\mathrm{w}$ tym okresie plan trzeciego roku stalinowskiej

8 „Prawda Wileńska”, R. 1, nr 57. 


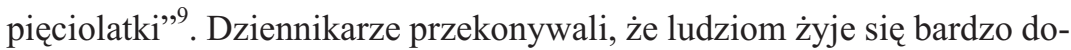
brze: „Wyjdziemy na ulice miast i wsi naszej republiki. Spójrzmy na twarze przechodniów - starców, dzieci, mężczyzn i kobiet - wszystkie radosne!" 10

Enuncjacje dotyczące polityki zagranicznej ZSRR w „Prawdzie Wileńskiej" były bardzo schematyczne. Wszystko, z pewnym wyjątkiem, co znajdowało się poza granicami komunistycznego państwa było godne potępienia. „Obecnie ludzkość ma dwa systemy ustroju, obumierający, gnijący i zdychający w mękach kryzysu oraz krwawych wojen - kapitalistyczny i młody, rozkwitający system socjalistyczny, w którym narody żyją szczęśliwie i zgodnie, wzbudzając ku sobie miłość pracujących wszystkich krajów"11. O III Rzeszy, zaliczanej do państw kapitalistycznych, pisano jednak bardzo dobrze. W tym przypadku „różnica systemu politycznego ideologicznego nie mogła i nie powinna była być przeszkodą niepokonaną dla urzeczywistnienia pokojowych i szczerze sąsiedzkich stosunków między obu państwami”" ${ }^{2}$. Podstawowym schematem, wbijanym do głów czytelników, przez prasę i całą propagandę sowiecką, była teza, że Związek Sowiecki prowadzi wyłącznie pokojową politykę, która przyniosła wielkie sukcesy na arenie międzynarodowej. Nie wspominano o wojnie z Finlandią. Aneksje kolejnych krajów tłumaczono tak: „kapitalizm zmuszony był ustapić i cofnąć się wobec rosnących i wzmacniających się sił socjalizmu”. Decydowała więc, w ujęciu „Prawdy Wileńskiej”, nie siła Armii Czerwonej, tylko atrakcyjność bolszewickiej ideologii. Dystansowano się wyraźnie od toczącej się wojny.

Longin Tomaszewski i Stanisław Wirski, charakteryzując całą polskojęzyczną prasę sowiecką, zwracali uwagę na jej zaangażowanie w dwóch kwestiach $^{13}$. Pierwszą było propagowanie ideologii bolszewickiej. Druga, szkalowanie wszystkiego, co związane było z polską suwerennością państwowa.. „Prawda Wileńska” przez cały okres swego istnienia prowadziła antypolską kampanię, posługując się także prymitywnymi kłamstwami i oszczerstwami. Starała się zabić w Polakach nadzieję na wskrzeszenie państwa i zniszczyć w nich poczucie odrębności narodowej i kulturowej,

9 „Prawda Wileńska”, R. 2, nr 1.

10 „Prawda Wileńska” R. 2, nr 1.

11 „Prawda Wileńska”, R. 1, nr 67.

12 „Prawda Wileńska”, R. 1, nr 6.

13 L. Tomaszewski, Kronika Wileńska 1939-41, Warszawa 1988, s. 88; S. Wirski, Polityka ZSRR wobec ziem polskich 1939-1941, Warszawa 1988, s. 28. 
nie dopuścić do myśli o jakimkolwiek oporze. Według gazety, Polacy mieszkający na obszarze ZSRR byli obywatelami sowieckimi, niemającymi nic wspólnego z rodakami znajdującymi się np. pod okupacją niemiecka, więc nic ich nie powinna obchodzić Warszawa czy Kraków. Nie wspominano o rządzie na uchodźstwie i armii polskiej. O Generalnym Gubernatorstwie pojawił się jeden artykuł, przedruk z „Das Reich”, szydzący z Polaków. Przedstawiono w nim GG jako olbrzymie pole doświadczalne dla przekształcających się Niemiec. O II Rzeczpospolitej pisano często i obszernie. Wykorzystywano znamienne rocznice na przykład podpisanie paktu Ribbentrop-Mołotow, 1 września, 17 września. Krytykowano państwo polskie za politykę społeczną i narodowościową: „Obszarniczo-burżuazyjne państwo polskie oparte było na skrajnym ucisku narodowościowo-socjalnym [...] ludność włościańska i robotnicza żyła w ekonomicznej niewoli potężnych karteli i syndykatów [...] poddana była polityce przymusowej polonizacji i pozbawiona dostępu do kultury. Terror policyjny był straszny, całe dzielnice Zachodniej Ukrainy padły ofiarą krwawych pacyfikacji, w których specjalne dobrane oddziały siepaczy paliły i burzyły wsie, niszczyły plony, katowały ludzi [...] W aresztach policyjnych i śledczych, a nawet w więzieniach katowano aresztowanych, wbijano im drzazgi pod paznokcie, wykręcano palce, stosowano torturę wodną"14. Równie kłamliwie pisano o przyczynach klęski wrześniowej: „Wojna się rozpoczęła, pierwszą jej ofiarą padło na wskroś przegniłe państwo Polski, które przystapiło do awantury wojennej na skutek słynnych «gwarancji» Londynu i Paryża"15. Wynika z tego, że to Polska rozpętała wojnę. Inwazję sowiecką przedstawiano jako obronę Ukraińców i Białorusinów przed okrucieństwem wojny, Armia Czerwona miała przekroczyć granicę po „haniebnej ucieczce polskiego rządu”. Zadaniem „Prawdy Wileńskiej" było zrywanie więzi narodowych, a nie ich wzmacnianie. Dlatego tylko kilka razy napisano o Polakach zamieszkujących w innej niż Litwa republice. Autorem owych tekstów, był Teodor Bujnicki, tematem przemiana Polaków mieszkających we Lwowie w lojalnych obywateli Związku Sowieckiego. Redaktor „Prawdy Wileńskiej” zachwycał się rozwojem twórczości „sowieckich literatów polskich”, m.in. Ważyka, Jastruna, Zana, Przybosia, Putramenta, którzy „wkomponowali się doskonale w potężne budownictwo socjalistyczne w ZSRR" "16. Bujnicki zazdrościł

\footnotetext{
14 „Prawda Wileńska”, R. 1, nr 28.

15 „Prawda Wileńska”, R. 1, nr 6.

16 „Prawda Wileńska”, R. 2, nr 34.
} 
osiągnięć literatom i proponował brać z nich przykład wileńskim kolegom po piórze.

Sprawy Wilna, chociaż zepchnięte na drugi plan, omawiano obszernie, gazeta była więc wileńska nie tylko z nazwy. Przedstawiano je w krzywym zwierciadle bolszewickich teorii politycznych i społecznych, wciskano wąski gorset propagandowych sloganów, publikacje w niewielkim stopniu odzwierciedlały więc rzeczywistość. Bardzo dużo miejsca zajmowały kampanie wyborcze i obchody sowieckich świąt państwowych. Na co dzień dominowała problematyka gospodarcza i społeczna. Rozpisywano się szeroko o dobrodziejstwach nacjonalizacji przemysłu, oddania ziemi bezrolnym, likwidacji bezrobocia, pozytywnych skutkach centralnego planowania. Polskość gazety miał podkreślać dział kulturalny, w którym odnotowywano wszelkie polskojęzyczne imprezy i wydarzenia. O prawdziwych problemach miasta świadczyć mogą ogłoszenia drobne. W rubryce „Lekarze” ogłaszali się gównie specjaliści od chorób skórnych i wenerycznych. Z informacji o tym, że skradziono „kurtkę i dokumenty”, wnioskujemy, że nie wszyscy zaangażowali się w budowę socjalizmu. Znakiem czasu była duża ilość osób poszukujących mieszkań i starających się sprzedać pianina i fortepiany.

Stosunek „Prawdy Wileńskiej” do kultury był jednoznaczny „całe życie kulturalne musi dążyć ku jednemu celowi. Wszystkie dziedziny życia duchowego - nauka, sztuka, szkoła, uniwersytety ludowe, prasa - powinny przyczynić się do chwalebnej pracy nad budową komunizmu pod przewodem partii" " ${ }^{\prime \prime}$. Wprowadzono sowiecki system nauczania i wychowania, wszyscy uczniowie musieli obowiązkowo uczyć się rosyjskiego. „W szkołach polskich zniesiono lub ograniczono do minimum naukę historii Polski, resztki dostosowując do sowieckiej propagandy"18. Przeprowadzono czystki wśród nauczycieli. Tych, którzy bronili polskiej kultury narodowej zwolniono lub aresztowano. Kadrę nauczycielską uzupełniono pedagogami sprowadzonymi z głębi Rosji. Teatry, kina i radio stały się narzędziami propagandy, choć pozwolono, pod kontrolą, na wystawianie „nieszkodliwych" sztuk polskich. Rozpoczęto też bezwzględną walkę z Kościołem i religią. Zamykano świątynie, aresztowano księży i zakonników. Zaczęła działać tzw. „liga bezbożników” propagująca ateizm drukiem, filmem

17 „Prawda Wileńska”, R. 1, nr 46.

18 W. Pobóg-Malinowski, Najnowsza historia Polski 1939-1945, Bydgoszcz 1990 , s. 116. 
i megafonem. Wiernych odciągano od Kościoła obietnicami nagród bądź groźbami aresztowania i deportacji. Bolszewicy uważali się za „wyłącznych, prawnych spadkobierców wszystkich zasobów kultury, jakie ludzkość kiedykolwiek stworzyła"19. Część dorobku kultury polskiej miała być włączona do sowieckiej, reszta zniszczona. Wykonawcą wyroku była także „Prawda Wileńska”. Na jej łamach drukowano życiorysy i próbki twórczości pisarzy polskich i poetów, których włączyć było można w bolszewicką ideologię, innych skazywano na zapomnienie.

Ogromnym ciosem była deportacja ludności, którą rozpoczęto 14 czerwca i kontynuowano aż do 23 czerwca $1941 \mathrm{r}$. Z Wilna wywieziono w głąb ZSRR około 7600 osób. O tych wydarzeniach, które zapadły w pamięć wszystkich Wilnian „Prawda Wileńska” milczała. 15 czerwca obchodzono rocznicę zajęcia Kowna przez oddziały sowieckie. Na pierwszej stronie umieszczono bijący w oczy tytuł: „Wielki Dzień Wyzwolenia”. W numerze z 18 czerwca zwraca uwagę obszerny artykuł o osiagnięciach w dziedzinie oświaty, przemysłu, ochrony zdrowia, opieki społecznej, handlu, etc. W ogłoszeniach drobnych ukazały się zaś dwa anonse o poszukiwaniu opiekunek do dzieci. Niewykluczone, że dotychczasowe były w drodze do bardzo odległych krajów azjatyckich.

Wydawane w Wilnie za czasów litewskich „Kurier Wileński” i „Gazetę Codzienną” można nazwać prasą polską. „Prawda Wileńska” nie wyrażała nadziei i myśli Polaków żyjących na Wileńszczyźnie, nie dbała o ich sprawy. Reprezentowała interesy partii komunistycznej, władz Związku Sowieckiego i sowieckiej Litwy, była uzupełnieniem siły Armii Czerwonej i terroru NKWD na Wileńszczyźnie Jako narzędzie propagandy sowieckiej starała się niszczyć niezależną myśl, zabić wolę oporu polskiej części społeczeństwa tego regionu. Gazety takie na terytorium Generalnego Gubernatorstwa nazywano „gadzinówkami”. Takie miano pasuje także do „Prawdy Wileńskiej”. W czasie wojny niektórzy pracownicy i współpracownicy niemieckich gazet polskojęzycznych byli sądzeni i skazywani, nawet na karę śmierci. Także po wojnie zapadały w ich sprawach wyroki skazujące. Praca w pismach sowieckich także była kolaboracją z wrogiem. Podziemny sąd Armii Krajowej skazał Teodora Bujnickiego za współpracę z „Prawdą Wileńską” na karę śmierci. Wyrok wykonano w 1944 roku. Po wojnie, w PRL-u, o karach za pracę w polskojęzycznych gazetach sowieckich nie mogło być już mowy, nie przeszkadzała w karie-

19 „Prawda Wileńska”, R. 1, nr 46. 
rze. Jeden z głównych redaktorów „Prawdy”, Stefan Jędrychowski, doszedł do stanowiska wicepremiera. Dziś oczywisty wydaje się jej prawdziwy charakter i negatywna ocena działalności.

\section{Summary}

In the times of the Polish People's Republic researchers into the history of the press from 1939 to 1945 focused on the territory of the General Government. After 1989 greater interest began to be concentrated on the part of the Republic of Poland that had been annexed by the USSR. The history of Vilnius during WWII is peculiar as the government changed several times there. The town changed hands between the Soviets, Lithuanians, Soviets again, then the Germans and eventually the Soviets. This has made the history of the Vilnius press from 1939 to 1944 also interesting. This paper presents the history of the daily press published in Vilnius in the Polish language in the period 1940-1941, that is when the town was occupied by the Soviets; particular attention is given to the most important daily - „Prawda Wileńska”. 
